\title{
Survey on Housing and Feeding Practices of Buffaloes Owners in Junagadh and Porbandar District of Gujarat, India
}

\author{
B.A. Pata, M.D. Odedra, A.R. Ahlawat*, H.H. Savsani and T.K. Patbandha \\ College of Veterinary Science \& A.H., Junagadh Agricultural University, \\ Junagadh - 362001, India \\ *Corresponding author
}

\section{A B S T R A C T}

\begin{tabular}{|c|}
\hline Keywords \\
\hline $\begin{array}{l}\text { Housing, Feeding, } \\
\text { Buffaloes, } \\
\text { Cottonseed cake }\end{array}$ \\
\hline Article Info \\
\hline $\begin{array}{l}\text { Accepted: } \\
\text { 08 July } 2018 \\
\text { Available Online: } \\
\text { 10 August } 2018\end{array}$ \\
\hline
\end{tabular}

The present investigation was carried out to study the feeding and housing patterns adopted by buffaloes keepers in Junagadh and Porbandar districts of Gujarat State. A random sample of 300 buffalo owners were selected from three talukas of Junagadh and two talukas of Porbandar district. Majority of buffalo owners $(55.67 \%)$ had animal shed located inside dwelling house with kuccha slopped floor (83.67\%). Most of buffalo owners reduced heat stress in buffaloes by splashing of water and $71 \%$ farmers adopted both stall feeding and grazing to their buffalo. In study area, $80 \%$ buffalo owners cultivated green fodder, $92.67 \%$ and $91 \%$ respondents did not feed salt and mineral mixture to their buffaloes, respectively. Most common green fodder used were maize and lucerne in the study area, $51.33 \%$ and $40 \%$ respondents fed maize and lucerne to their buffaloes respectively. Sorghum straw $(33.33 \%)$ and groundnut gotar $(61.67 \%)$ were fed as dry fodder to their buffaloes. Majority of buffalo owners $(95.33 \%)$ did not offer bypass fat/protein to their buffaloes and $71.67 \%$ buffalo owners fed cottonseed cake to their buffaloes.

\section{Introduction}

Livestock sector of India is one of the largest sectors in the world, comprising of 11.6 per cent of total livestock population of the world. Livestock plays an important role in Indian economy and provides livelihood to two-third of rural community. It also provides employment to about 8.8 per cent of the human population in India. India continues to be the largest producer of milk in the world. Total milk production during 2016-17 was 165.4 million tones. The per capita availability of milk was around 355 grams per day in 2016-17 (Anon., 2017).

The buffalo holds an important place in Indian rural economy. Buffalo is the premier animal in Indian dairy industry contributing about $60 \%$ of total milk production in the country. Buffaloes are preferred over cattle in India because of their distinctive qualities such as better feed conversion efficiency, more resistance to diseases and higher milk fat percentage than in cows (Bandyopadhyay et al., 2003). Feeding, housing and health 
management plays a very significant role in exploiting the full potential of dairy animals. The management practices constitute about 75-80 per cent of total cost incurred on milk production in dairy business (Verma and Sastry, 1994). Insufficient feeding results in poor growth, delayed maturity, late conception and poor production. Provision of comfortable and proper spacing is helpful in reducing the energy in maintaining thermoneutral zone and also provides ideal, comfortable and hygienic conditions, which reduce the incidence of diseases, lower the pathogenic load, reduces the ecto and endo parasites and provides good environment for optimum milk production. The performance and productivity of buffaloes in the region appears to be at low level and the factors responsible need greater attention. Productivity of an animal is primarily the product of interaction of its genetic makeup and the environment in which it develops. The findings of the present study will provide a physical and relevant package of buffalo husbandry practices adopted by the farmers of this region, so that the farmers of the other region in the country are also benefited.

\section{Materials and Methods}

The present study was carried out in villages of Junagadh and Porbandar districts of Gujarat state. It was selected due to presence of large number of buffaloes, buffalo rearing farmers, familiarity of researcher with the area and local language and his ability to cover larger area within stipulated time. Two talukas from Porbandar viz Porbandar and Kutiyana and three talukas from Junagadh viz Keshod, Mangrol and Manavadar were selected and from each selected taluka 6 villages were chosen randomly. Thus samples of 300 buffalo owners were selected for the study. While selecting respondents due care was taken to ensure that they were evenly distributed in the village and were a true representative of animal management practices prevailing in the area the selected respondents were interviewed personally and information was collected with the help of predesigned questionnaire The variables under study were selected on the basis of extensive review of literature related to the topic of research and consultation with experts. The data with regards housing and feeding management, milking management and health management as well as the constraints in adoption of management practices involved were also collected. All the data were classified and tabulated carefully while compiling the information.

\section{Statistical analysis of the data}

Collected data were compiled, tabulated and analyzed using appropriate statistical tools and techniques like percentage, mean, frequency and standard deviation were calculated.

\section{Results and Discussion}

\section{Housing management practices}

The data on the housing pattern adopted by the farmers of the two districts has been shown in table 1.

Housing takes care of the comfort of animals as well as economics. Housing in most of the rural areas is not proper and the dairy sheds should be widely located, properly oriented, constructed, spaced out and grouped.

Studies revealed that majority of respondents (55.67 per cent) had buffalo shed located inside dwelling house while 44.33 per cent had separate shed outside their house. These findings are contrary to Pundir et al., (2000) who found that in about 75 per cent of cases, the farmer and animal houses were separate. There were no significant differences found 
between the Junagadh and Porbandar district for location of buffalo shed.

Majority of respondents (55.67 per cent) had kuccha floor pattern followed by 44.33 per cent pucca floor pattern. These findings are supported by Kalyankar et al., (2008) who found that the kuccha flooring was most common (91.56 per cent) in animal houses. Present findings were also supported by Sabapara et al., (2010) who also reported kaccha flooring to be most common type of flooring in his study area.

Observations in Table 1 indicated that 83.67 per cent buffalo sheds had slope in floor however very few (16.33 per cent) sheds did not contain slope. These findings are supported by Kumar et al., (2017) who revealed that 54.17 per cent houses have slope for proper drainage of urine and faeces. There was no significant difference found between the Junagadh and Porbandar district for slope in floor in buffalo shed.

It was found that 21.67 per cent of the dairy animal owners used sheds with drainage channel/pit while 78.33 per cent respondents used sheds that did not contain drainage channel/pit. These findings are supported by Ghuge (2014) and Atakare et al., (2016). Significant differences were found between the Junagadh and Porbandar district. Also 87.33 per cent respondents practiced manger feeding followed by 12.67 per cent who did not practice manger feeding. These findings are in contrary to Vranda et al., (2017) who found that the manger was not provided by majority of the farmers in her study area. There was no significant difference found between the Junagadh and Porbandar district with regard to manger feeding pattern.

The majority of respondents ( 87.33 per cent) provided proper light and ventilation to buffalo shed followed by 12.67 per cent respondents who did not provide proper light in buffalo shed. These results are supported by Vranda et al., (2017). There was a significant difference found between the Junagadh and Porbandar district for provision of proper light to animal shed.

It was also inferred that 76.67 per cent respondents had buffalo shed containing single slope roof and 23.33 per cent buffalo shed had double slope roof. These results are supported by Ghuge (2014) and Atakare et al., (2016). There was no significant difference found between the Junagadh and Porbandar district for roof patterns.

About 78 per cent owners splashed water on buffaloes to reduce heat stress followed by 22 per cent buffalo owners who practiced wallowing in their buffaloes. These results are contrary to Kishore et al., (2013) who reported that as a part of summer management, $51 \%$ farmers allowed their buffaloes to wallow in the village tanks during the hotter parts of the day and $49.16 \%$ farmers washed their animals by splashing water manually. There was no significant difference found between the Junagadh and Porbandar district related to summer management practices followed by buffalo owners.

\section{Feeding management practices}

The data on the feeding patterns adopted by the farmers of the two districts has been shown in table 2 .

Feeding is one of the most important aspect of milk production. For optimum milk production, balanced and adequate feeding is important. Data are collected and presented in table 2.

From the present investigation it was observed that 71 per cent practiced of 
respondents fed both (stall+ grazing) followed by 16.67 per cent who practiced stall feeding and 12.33 per cent who practiced grazing alone. These findings are supported by Manohar et al., (2014) who reported that 87.50 per cent of farmers followed grazing +stall feeding system. There were significant differences between Junagadh and Porbandar district.

It was found that majority of respondents $(80$ per cent) cultivated green fodder followed by 20 per cent farmers who did not cultivate green fodder. These findings are similar to Kumar et al., (2005) who found that majority $(80 \%)$ of buffalo farmers cultivated the fodder for their animals, present findings were also supported by Dhaliwal and Dhillon (2017) who reported that cultivated fodder crops (68 per cent) for feeding to dairy animals throughout the year. There was no significant difference found between the Junagadh and Porbandar district in relation to cultivation of fodder.

Out of total respondents 92.67 per cent did not feed salt to buffaloes while 7.33 per cent buffalo owners fed salt to buffaloes. These results are supported by Jadav et al., (2014) who indicated that 76 per cent did not provide salt to animals. There was no significant difference found between the Junagadh and Porbandar district related to fed of common salt to buffaloes.

About 91 per cent of buffalo owners did not feed mineral mixture to buffaloes while 9 per cent buffalo owners fed mineral mixture to buffaloes. These results are supported by Jadav et al., (2014) and Jatoliya et al., (2017) who studied that only 31 per cent of the farmers provide mineral mixture to their buffaloes and 69 per cent did not provide mineral mixture to their buffaloes. There was no significant difference found between the Junagadh and Porbandar district related to fed of mineral mixture to buffaloes. Observations suggested that 51.33 per cent respondents offered maize, 40 respondents offered Lucerne and 4 per cent respondents also offered jinjvo as green fodder to their animals however 4.67 respondents did not offer any green fodder to their buffaloes. Mandal et al., (2004) studied that berseem was the major green fodder and green oat offered to animals in Faridabad district of Haryana state. The variation of feeding of various types of green fodder in different places may be due to cultivation of the fodder crop in the area. In Junagadh district 61.67 per cent respondents offered maize as green fodder to their buffaloes. However in Porbandar district more no. of respondents offered lucerne as green fodder to their buffaloes $(50.84 \%$ vs.32.78\%). Most of respondents (61.67 per cent) offered groundnut gotar as dry fodder followed by 33.33 respondents who offered sorghum straw as dry fodder followed by 5.00 per cent respondents did not offer any dry fodder to their buffaloes. Garg et al., (2005) reported that wheat straw (68.75 per cent) was most commonly fed followed by soyabean straw (25 per cent) and jowar kadbi (6.25 per cent) in Baran district of Rajasthan state.In Junagadh district higher number. of respondents offered sorghum as dry fodder to their buffaloes (37.78\% vs. $26.67 \%)$.

The present study also indicated that 4.67 per cent respondents offered bypass fat/protein while 95.33 per cent respondents did not offer bypass fat/protein to their buffaloes. There was no significant difference found between the Junagadh and Porbandar district related to fed of bypass fat/protein to buffaloes. Also 92 per cent respondents offered as such green fodder however 8 per cent respondents offered chafed green fodder to their buffaloes. These results are contrary with Manohar et al., (2014) who studied that 100 per cent farmers chaffed both green and dry fodder. In Junagadh district more no. of respondents 
offered green fodder as such to their buffaloes (94.44\% vs. $88.33 \%, \mathrm{P} \leq 0.05)$ compared to Porbandar district. This may be due to lack of adequate knowledge of efficient utilization of feed and fodder.

It was also revealed that 65.67 per cent respondents offered their animals concentrate during milking, 23.67 per cent respondents did not offer concentrate to their buffaloes, 7.33 per cent respondents offered concentrate before milking while 3.33 per cent respondents offered concentrate after milking. Jadav et al., (2014) studiedthat17 per cent of respondents offered concentrate during milking. In Junagadh district more number of respondents offered concentrate during milking to their buffaloes compared to Porbandar district ( 72.78 vs. $55 \%$ ) while in Porbandar district more number of respondents offered concentrate after milking compared to Junagadh district to their buffaloes $(6.67 \%$ vs. $1.11 \%)$. However in Porbandar district more number of respondents did not offer concentrate to their buffaloes compared to Junagadh district (30\% vs. $19.45 \%, \mathrm{P} \leq 0.05)$.

Table.1 Distribution of the buffalo owners according to housing practices

$(n=300)$

\begin{tabular}{|c|c|c|c|c|c|}
\hline $\begin{array}{l}\text { Sr. } \\
\text { no. }\end{array}$ & Particulars & Junagadh & Porbandar & Overall & $\begin{array}{l}\text { Chi square } \\
\text { value }\end{array}$ \\
\hline \multirow[t]{3}{*}{1} & \multicolumn{5}{|l|}{ Location of shed } \\
\hline & Inside dwelling house & $57.78(104)$ & $52.5(63)$ & $55.67(167)$ & \multirow[t]{2}{*}{0.813} \\
\hline & Separate from dwelling house & $42.22(76)$ & $47.5(57)$ & $44.33(133)$ & \\
\hline \multirow[t]{3}{*}{2} & \multicolumn{5}{|l|}{ Types of floor } \\
\hline & Kuccha & $66.10(119)$ & $40.00(48)$ & $55.67(167)$ & \multirow[t]{2}{*}{$19.981 * *$} \\
\hline & Pucca & $33.89(61)$ & $60.00(72)$ & $44.33(133)$ & \\
\hline \multirow[t]{3}{*}{3} & \multicolumn{5}{|l|}{ Slope in floor } \\
\hline & Yes & $86.67(156)$ & 79.17(95) & $83.67(251)$ & \multirow[t]{2}{*}{2.964} \\
\hline & No & $13.33(24)$ & $20.83(25)$ & $16.33(49)$ & \\
\hline \multirow[t]{3}{*}{4} & \multicolumn{5}{|l|}{ Drainage channel / pit } \\
\hline & Yes & $22.22(40)$ & $20.83(25)$ & $21.67(65)$ & \multirow[t]{2}{*}{ 4.861* } \\
\hline & No & $77.78(140)$ & 79.17(95) & $78.33(235)$ & \\
\hline \multirow[t]{3}{*}{5} & \multicolumn{5}{|l|}{ Manger feeding: } \\
\hline & Yes & $87.22(157)$ & $87.5(105)$ & $87.33(262)$ & \multirow[t]{2}{*}{0.005} \\
\hline & No & $12.78(23)$ & $12.5(15)$ & $12.67(38)$ & \\
\hline \multirow[t]{3}{*}{6} & \multicolumn{5}{|c|}{ Proper light provision animal shed: } \\
\hline & Yes & $92.78(167)$ & $79.17(95)$ & $87.33(262)$ & \multirow[t]{2}{*}{$12.058 * *$} \\
\hline & No & $7.22(13)$ & $20.83(25)$ & $12.67(38)$ & \\
\hline \multirow[t]{3}{*}{7} & \multicolumn{5}{|l|}{ Features of roof of shed } \\
\hline & Single slope & $77.78(140)$ & $75.00(90)$ & $76.67(230)$ & \multirow[t]{2}{*}{0.311} \\
\hline & Double slope & $22.22(40)$ & $25.00(30)$ & $23.33(70)$ & \\
\hline \multirow[t]{3}{*}{8} & \multicolumn{5}{|c|}{ Other (Summer management practices) } \\
\hline & Wallowing & $23.33(42)$ & $20.00(24)$ & $22.00(66)$ & \multirow[t]{2}{*}{0.466} \\
\hline & Splashing of water & $76.67(138)$ & $80.00(96)$ & $78.00(234)$ & \\
\hline
\end{tabular}


Table.2 Distribution of buffalo owners according to feeding practices $(n=300)$

\begin{tabular}{|c|c|c|c|c|c|}
\hline $\begin{array}{l}\text { Sr. } \\
\text { no. }\end{array}$ & Particulars & Junagadh & Porbandar & Overall & $\begin{array}{l}\text { Chi square } \\
\text { value }\end{array}$ \\
\hline \multirow[t]{4}{*}{1} & \multicolumn{3}{|c|}{ Feeding system of animals } & & \\
\hline & Stall feeding & $9.44(17)$ & $27.5(33)$ & $16.67(50)$ & $16.900 * *$ \\
\hline & Only Grazing & $15.00(27)$ & $8.33(10)$ & $12.33(37)$ & 2.960 \\
\hline & Both $($ stall + grazing $)$ & $75.56(136)$ & $64.17(77)$ & $71.00(213)$ & 4.536* \\
\hline \multirow[t]{3}{*}{2} & \multicolumn{5}{|c|}{ Cultivation of green fodder } \\
\hline & Yes & $83.33(150)$ & $75(90)$ & $80.00(240)$ & \multirow[t]{2}{*}{3.125} \\
\hline & No & $16.67(30)$ & $25(30)$ & $20.00(60)$ & \\
\hline \multirow[t]{3}{*}{3} & \multicolumn{5}{|l|}{ Feeding of common salt } \\
\hline & Yes & $6.67(12)$ & $8.33(10)$ & $7.33(22)$ & \multirow[t]{2}{*}{0.294} \\
\hline & No & $93.33(168)$ & $91.67(110)$ & $92.67(278)$ & \\
\hline \multirow[t]{3}{*}{4} & \multicolumn{5}{|c|}{ Feeding of mineral mixture } \\
\hline & Yes & $7.78(14)$ & $10.83(13)$ & $9.00(27)$ & \multirow[t]{2}{*}{0.821} \\
\hline & No & $92.22(166)$ & $89.17(107)$ & $91.00(273)$ & \\
\hline \multirow{5}{*}{5} & \multicolumn{5}{|l|}{ Type of green fodder } \\
\hline & Maize & $61.67(111)$ & $35.83(43)$ & $51.33(154)$ & $19.234 * *$ \\
\hline & Lucerne & $32.78(59)$ & $50.84(61)$ & $40.00(120)$ & $9.780 * *$ \\
\hline & other(Jinjvo) & $3.33(6)$ & $5.00(6)$ & $4.00(12)$ & 0.521 \\
\hline & None & $2.22(4)$ & $8.33(10)$ & $4.67(14)$ & 6.044 \\
\hline \multirow{4}{*}{6} & \multicolumn{5}{|l|}{ Type of dry fodder } \\
\hline & Sorghum straw & $37.78(68)$ & $26.67(32)$ & $33.33(100)$ & $4.000 *$ \\
\hline & Ground nut gotar & $57.58(104)$ & $67.50(81)$ & $61.67(185)$ & 2.879 \\
\hline & None & $4.44(8)$ & $5.83(7)$ & $5.00(15)$ & 0.145 \\
\hline \multirow[t]{3}{*}{7} & \multicolumn{5}{|c|}{ Bypass protein /fat feeding } \\
\hline & Yes & $4.44(8)$ & $5.00(6)$ & $4.67(14)$ & \multirow[t]{2}{*}{0.050} \\
\hline & No & $95.66(172)$ & $95.00(114)$ & $95.33(286)$ & \\
\hline \multirow[t]{3}{*}{8} & \multicolumn{5}{|l|}{ Green fodder fed } \\
\hline & As such & $94.44(170)$ & $88.33(106)$ & $92.00(276)$ & \multirow{2}{*}{$3.653 *$} \\
\hline & Chaffed & $5.56(10)$ & $11.67(14)$ & $8.00(24)$ & \\
\hline \multirow[t]{5}{*}{9} & \multicolumn{5}{|c|}{ Time of feeding concentrate } \\
\hline & During milking & $72.78(131)$ & $55.00(66)$ & $65.67(197)$ & $10.093 * *$ \\
\hline & After milking & $1.11(2)$ & $6.67(8)$ & $3.33(10)$ & $6.897 *$ \\
\hline & Before milking & $6.67(12)$ & $8.33(10)$ & $7.33(22)$ & 0.294 \\
\hline & No feeding & $19.45(35)$ & $30.00(36)$ & $23.67(71)$ & $4.441 *$ \\
\hline \multirow[t]{4}{*}{10} & \multicolumn{5}{|l|}{ Type of concentrate } \\
\hline & Cotton seed cake & $77.22(139)$ & $63.33(76)$ & $71.67(215)$ & $6.840 *$ \\
\hline & Compound cattle feed & $3.33(6)$ & $6.67(8)$ & $4.66(14)$ & 1.798 \\
\hline & None & $19.45(35)$ & $30.00(36)$ & $23.67(71)$ & $4.441 *$ \\
\hline
\end{tabular}


The majority of respondents (71.67 per cent) fed cotton seed cake as concentrate followed by 4.66 per cent respondents who offered compound cattle feed as concentrate and 23.67 per cent who did not fed concentrate to their buffaloes. Similar findings were observed by Kumar et al., (2005) who reported that majority $(63.89 \%)$ of respondents used home prepared concentrate like barley, wheat bran etc., whereas 36.11 per cent respondents purchased readymade concentrates from local market.

In Junagadh district more number of respondents offered cottonseed cake as concentrate as compared to Porbandar district (77.22\% vs.63.33\%, P $\leq 0.01)$. However in Porbandar district more number of respondents did not offer concentrate to their buffaloes compare to Junagadh district. The non-feeding of additional supplements to the pregnant animals and of mineral mixture to all animals clearly indicates that productive animals were facing shortages of nutrients which would inhibit their exhibiting their performance. This might have been due to a lack of scientific feeding knowledge among the buffalo farmers, high costs and feed and mineral mixtures or non-availability etc (Kishore et al., 2013).

In conclusions, the present study revealed that majority of buffalo owners (92.67 per cent) did not fed salt to their buffaloes. Also Majority of buffalo owners (91 per cent) did not fed mineral mixture to buffaloes and only 8 per cent respondents offered chaffed green fodder to their buffaloes. Only 21.67 per cent shed contained drainage channel/pit and 78.33 per cent shed did not contain drainage channel/pit.

There is still considerable gap between existing management and feeding practices and the recommended scientific practice.
Training/ awareness programmes on improved managemental and feeding practices shall help farmers overcome these problems.

\section{References}

Anonymous, (2017). District; a profile, retrieved from: Gujarat.nic.in/pg district Profile.html, Downloaded from: en.wikipedia.org/wiki.

Atkare, V.G., Khupse S.M. and Darade, R. (2016).Feeding and management practices adopted by local milch buffalo owners under field condition of Gadchiroli tahsil. The Asian Journal of Animal Science, 11(2): 154-168.

Bandyopadhyay, A.K., Ray, R. R. and Ghatak, P. K. (2003). In proc: Effective utilization of buffalo milk for manufacturing dairy products. $4^{\text {th }}$ Asian buffalo congress, held at New Delhi from 25-28 Feb: 191.

Dhaliwal, A. P. S. and Dhillon, G. S. (2017).Management practices followed by dairy farmers in rural and urban areas of Bathinda district in Punjab. Journal of Krishi Vigyan, 6(1): 124127.

Garg, M. K., Jain, L. S. and Chaudhari, S. L. (2005). Studies on housing feeding and milk management practices of dairy cattle in Baran district of Rajasthan. Indian Journal of Dairy Science, 58(2): 123-128.

Ghuge S. S. (2014). Studies on Feeding Management Practices Adopted for Cattle in Sugarcane Pockets of Nanded District. M.Sc.(Agri.) Thesis Submitted to VNMKV, Parbhani, Maharastra.

Jadav, S. J., Rani, D. V., Pansuriya, D. V., Chaudhary, J. H., Chauhan, V.D. and Pandya S. S. (2014). Feeding practices of dairy animals in periurban areas of Surat district (Gujarat). International 
Journal Advanced Multidisciplinary Research, 1(3): 1-5.

Jatolia, P., Chandra S.J., Meena, S. M., Lawania, P., Bugaliya, H. L. and Kumar, D. (2017). Existing management practices of buffaloes owners in Udaipur district of Rajasthan. International Journal of Current Microbiology and Applied Sciences, 6(8): 2103-2108.

Kishore, K., Mahender, M. and Harikrishna, Ch. (2013). A study on buffalo management practices in Khammam district of Andhra Pradesh. Buffalo Bulletin, 32(2): 97-119.

Kumar, M., Mehla, R. K. and Chandra, R. (2005). Feeding and housing manage mental practices of Nilli-Ravi buffaloes under field conditions. Indian Journal of Animal sciences, 58: 376-378.

Kalyankar, S. D., Chavan, C. D.,Khedkar, C. D. and Kalyankar, S. P. (2008). Studies on management practices of buffaloes in different agro-climatic zones of Maharashtra. Indian Journal of Animal Research, 42(3): 157-163.

Kumar, Y. and Shukla, S. K. (2017).Constraints faced in adoption of improved management practices by rural and urban weaker section milk producers in Bulandshahr district of U.P. Research Journal of Animal Husbandry and Dairy Science, 8(1):1319.

Mandal, A. B., Yadav, P. S. and Kapoor, V. (2004). Mineral status of buffaloes under farm feeding condition of
Faridabad district of Haryana state. Indian Journal of Animal Nutrition, 21(2): 104-110.

Manohar, D. S., Goswami, S. C. and Bias B. (2014). Study on feeding management practices of buffaloes in relationship with selected traits of respondents in Jaipur District of Rajasthan. Indian Journal of Animal Research, 48(2): $150-154$.

Pundir, R. K., Sahana, G., Navani, N. K., Jain, P. K., Singh, D. V., Satish, K. and Dave, A.S. (2000). Characterization of Mehsani buffaloes in India. Animal Genetic Resources Information, 28(1): 53-62.

Sabapara, G. P., Desai, P. M., Kharadi, V. B., Saiyed, L. H. and Singh, R. R. (2010). Housing and feeding management practices of dairy animals in the tribal area of South Gujarat. Indian Journal of Animal Sciences, 80(10): 1022-1027.

Verma, A. K. and Sastri, N. S. R. (1994). Comparison of Buffalo housing practices prevalent in rural Haryana with organized farm, p. 21- 23. In Proceedings of National Symposium on Livestock Production and Management held at Anand, Gujarat, India.

Vranda, R. K., Satyanarayan, V., Jagadeeswary, K.C., Veeranna, Y.B., Rajeshwari, Y. B., Sudha, G. and Shree J.S. (2017). A study on different housing practices of buffaloes in Bidar district of Karnataka. International Journal of Science, Environment and Technology, 6(1): 295-302.

\section{How to cite this article:}

Pata, B.A., M.D. Odedra, A.R. Ahlawat, H.H. Savsani and Patbandha, T.K. 2018. Survey on Housing and Feeding Practices of Buffaloes Owners in Junagadh and Porbandar District of Gujarat, India. Int.J.Curr.Microbiol.App.Sci. 7(08): 1195-1202. doi: https://doi.org/10.20546/ijcmas.2018.708.134 